AN IMPROVED HALO METHOD FOR EVALUATING THE ANTIBACTERIAL ACTIVITY OF LEATHER

\author{
Jinwei ZHANG ${ }^{1,2}$, Qiuyue TANG ${ }^{1,2}$, Wuyong CHEN ${ }^{1,2}$, Hongbin SUN ${ }^{3}$, Qiming OU ${ }^{4}$, Yonghan WEN ${ }^{4 *}$ \\ ${ }^{1}$ National Engineering Laboratory for Clean Technology of Leather Manufacture, Sichuan University, Chengdu 610065, P. R. China \\ ${ }^{2}$ The Key Laboratory of Leather Chemistry and Engineering of Ministry of Education, Sichuan University, Chengdu 610065, P. R. China \\ ${ }^{3}$ Guangdong Shengfang Chemical Corporation, Jiangmen 529162, China \\ ${ }^{4}$ Guangdong Jiangmen Supervision Testing Institute of Quality and Metrology, Jiangmen 529000, China
}

Received: 14.05 .2020

Accepted: 17.07 .2020

https://doi.org/10.24264/Ifj.20.3.2

\title{
AN IMPROVED HALO METHOD FOR EVALUATING THE ANTIBACTERIAL ACTIVITY OF LEATHER
}

ABSTRACT. In order to evaluate leather antibacterial activity rapidly and accurately, an improved halo method was developed based on conventional halo method and the agar diffusion plate method. During the new method, there were two layers of medium, the bottom was sterile medium and the top was medium containing microbes; more than one leather sample could be tested in a culture dish. The antibacterial activities of leather treated by nano-silver, nano-ZnO and butyl paraben against Escherichia coli, Staphylococcus aureus, Aspergillus niger and Rhodotorula mucilaginosa were tested by the new method. The results indicated intraclass correlation coefficient values were greater than 0.7 but the $P$ values were less than 0.05 during improved halo method testing, thus, the repeatability and reliability was comparable or even better than conventional method. Nano-silver showed excellent and broad antibacterial activity and the difference between each antibacterial agent could be observed clearly and intuitively during improved halo method testing. In sum, improved halo method was a fast, accurate, qualitative and quantitative testing method and would be a new choice for evaluating leather antibacterial activity. KEY WORDS: leather, antibacterial activity, evaluation method, improved halo method

O METODĂ ÎMBUNĂTĂȚITĂ DE DETERMINARE A ZONEI DE INHIBARE PENTRU EVALUAREA ACTIVITĂȚII ANTIBACTERIENE A PIELII REZUMAT. Pentru a evalua rapid și precis activitatea antibacteriană a pielii, a fost dezvoltată o metodă îmbunătățită pe baza metodei de determinare a zonei de inhibare convențională și metodei plăcilor de difuzie de agar. În cadrul noii metode, au existat două straturi de mediu, partea inferioară a reprezentat mediu steril și partea superioară un mediu conținând microbi; mai multe probe de piele pot fi testate întrun vas de cultură. S-a testat activitatea antibacteriană a pielii tratate cu nano-argint, nano-ZnO și butil paraben împotriva Escherichia coli, Staphylococcus aureus, Aspergillus niger și Rhodotorula mucilaginosa prin noua metodă. Rezultatele au indicat valori ale coeficientului de corelație intraclasă mai mari decât 0,7 , dar valorile $\mathrm{P}$ au fost mai mici de 0,05 în cazul testării prin metoda îmbunătățită, astfel, repetabilitatea și fiabilitatea au fost comparabile sau chiar mai bune comparativ cu metoda convențională. Nano-argintul a demonstrat o activitate antibacteriană excelentă și pe scară largă, iar diferența dintre agenții antibacterieni a putut fi observată clar și intuitiv în timpul testării prin metoda îmbunătățită. În concluzie, metoda îmbunătățită de determinare a zonei de inhibare este o metodă de testare rapidă, precisă, calitativă și cantitativă și poate fi o alternativă pentru evaluarea activității antibacteriene a pielii.

CUVINTE CHEIE: piele, activitate antibacteriană, metodă de evaluare, metodă îmbunătățită de determinare a zonei de inhibare

\section{UNE MÉTHODE AMÉLIORÉE DE DÉTERMINATION DE LA ZONE D’INHIBITION POUR L'ÉVALUATION DE L'ACTIVITÉ ANTIBACTÉRIENNE DU} CUIR

RÉSUMÉ. Afin d'évaluer l'activité antibactérienne du cuir rapidement et avec précision, une méthode améliorée a été développée basée sur la méthode conventionnelle de détermination de la zone d'inhibition et la méthode de diffusion d'agar. Au cours de la nouvelle méthode, il y avait deux couches de milieu, la partie inférieure était un milieu stérile et la partie supérieure un milieu contenant des microbes ; plus d'un échantillon de cuir pourrait être testé dans une boîte de culture. Les activités antibactériennes du cuir traité par le nano-argent, le nano$\mathrm{ZnO}$ et le butyl paraben contre Escherichia coli, Staphylococcus aureus, Aspergillus niger et Rhodotorula mucilaginosa ont été testées par la nouvelle méthode. Les résultats ont indiqué que les valeurs des coefficients de corrélation intraclasse étaient supérieures à 0,7 mais les valeurs $\mathrm{P}$ étaient inférieures à 0,05 lors des tests de la méthode améliorée, ainsi, la répétabilité et la fiabilité étaient comparables ou même meilleures que la méthode conventionnelle. Le nano-argent a montré une excellente et large activité antibactérienne et la différence entre chaque agent antibactérien a pu être observée clairement et intuitivement lors de la méthode améliorée. En résumé, la méthode améliorée de détermination de la zone d'inhibition était une méthode d`essai rapide, précise, qualitative et quantitative et constituerait un nouveau choix pour évaluer lsactivité antibactérienne du cuir. MOTS CLÉS : cuir, activité antibactérienne, méthode d'évaluation, méthode améliorée de détermination de la zone d’inhibition

\footnotetext{
* Correspondence to: Yonghan WEN, Guangdong Jiangmen Supervision Testing Institute of Quality and Metrology, Jiangmen 529000, China, gdjmyonghan@163.com
} 


\section{INTRODUCTION}

Leather mainly consists of crosslinked collagen after being processed by a huge amount of chemical and mechanical procedures. As there are abundant nutriments in leather, such as protein, carbohydrate, fat, leather is an ideal harbor for bacteria and fungi reproduction. Microbe growth leads to unpleasant odor, skin infection, low product quality and other related issues, therefore, there is necessary to develop leather with excellent antibacterial properties [1, 2].

In leather industry, there are many research studies on antibacterial agents and antibacterial leather, in which nano-silver is widely used [3]. A kind of nano-silver was prepared by using sodium borohydride as reductant and benzalkonium bromide as protective agent [4], and it had been used for producing antibacterial leather and fur [5-8]. Evaluation of the antibacterial activity of leather is one of the most important work and basis for applying and spread antibacterial leather, but the standard method for the tests is rare and method is a little bit complicated and time-consuming [9]. The most widely used methods for evaluation of antibacterial activity are minimum inhibitory concentration and halo method $[10,11]$. Halo method can be used to evaluate leather antibacterial activity qualitatively, but only one sample is available per time. Microorganism inhibiting ring test could measure several samples during one experiment. The combination of halo method and microorganism inhibiting ring test would accelerate antibacterial activity evaluation efficiency.

In the study, a new method for evaluation of antibacterial activity of leather was proposed based on inhibition zone method and agar diffusion plate method with some modifications and improvements, named improved halo method, and the effect, accuracy, reliability and repeatability of improved halo method were compared with traditional halo method and agar diffusion plate method. The new method would be applied practically for measuring antibacterial activity of leather produced by nano-silver, nano-ZnO and butyl paraben. The new improved halo method would be new choice for evaluating leather antibacterial activity rapidly and precisely.

\section{EXPERIMENTAL}

\section{Materials}

The strains of bacteria and fungi used in this study were Staphylococcus aureus, Escherichia coli, Rhodotorula mucilaginosa and Aspergillus niger, which were all isolated from the shoes worn by children $[12,13]$. Staphylococcus aureus, Escherichia coli, Aspergillus niger and Rhodotorula mucilaginosa represented the gram-positive bacteria, gram-negative bacteria, mould and yeast, respectively. The beef extract peptone medium was used to culture the bacteria and the rose-bengal medium was used to culture the yeast and mould.

Nano-silver antibacterial agent with average particle size $26 \mathrm{~nm}$ and silver concentration $0.024 \mathrm{~g} / \mathrm{L}$ [4], $0.1 \% \mathrm{w} / \mathrm{w}$ nano-ZnO antibacterial agent with average particle size 51.8 $\mathrm{nm}$ [14] and $60 \mathrm{~g} / \mathrm{L}$ butyl paraben antibacterial agent [15] were prepared in laboratory. The chrome tanned pig shoe-lining leathers used in these tests were from a local tannery. Other reagents were research grade.

\section{Sample Preparation}

\section{Preparation of Microbe Suspensions}

$5 \times 10^{5}-5 \times 10^{6} \mathrm{cfu} / \mathrm{mL}$ bacterial suspensions: a $4 \mathrm{~mm}$ inoculating loop was used to scrape one loop of pure bacteria off the medium, and the bacteria were cultured in $100 \mathrm{~mL}$ fluid medium for $24 \mathrm{~h}$, then $1 \mathrm{~mL}$ bacterial suspensions into $100 \mathrm{~mL}$ physiological saline solution $(0.85 \%$, $\mathrm{w} / \mathrm{w})$; finally, the bacteria solution with some glass balls were shaken in a vibrator at $37^{\circ} \mathrm{C}$ for 2 h until well dispersing.

$5 \times 10^{5}-5 \times 10^{6} \mathrm{cfu} / \mathrm{mL}$ fungi spores or yeast suspensions: a $4 \mathrm{~mm}$ inoculating loop was used to scrape five loops of pure spores off the medium, and the spores were shaken in a vibrator at $28^{\circ} \mathrm{C}$ for $2 \mathrm{~h}$ until well dispersing. 


\section{Preparation of Antibacterial Leather Samples}

Antibacterial leather treated with nanosilver: Leather samples were completely soaked in nano-silver antibacterial agent solution at $25^{\circ} \mathrm{C}$ for $1.5 \mathrm{~h}$, and then the samples were taken out by sterile and dried in the air.

Antibacterial leather treated with nanoZnO: Leather samples were completely soaked in nano-ZnO antibacterial agent solution at $25^{\circ} \mathrm{C}$ for $18 \mathrm{~h}$, and then the samples were taken out by sterile and dried in the air.

Antibacterial leather treated with butyl paraben: Leather samples were completely soaked in butyl paraben antibacterial agent at $25^{\circ} \mathrm{C}$ for $3 \mathrm{~h}$, and then the samples were taken out by sterile and dried in the air.

\section{Antibacterial Activity Evaluation Method}

\section{Halo Method}

$18 \mathrm{~mL}$ sterile medium was poured into 120 $\mathrm{mm}$ sterile culture dish until become solid, and then $0.2 \mathrm{~mL}$ different microbe suspensions was put onto the medium surface and dispersed by sterile glass rods. Leathers were cut into circular samples with a diameter of $18 \mathrm{~mm}$ and the samples were placed on center of the dish. The dish inoculated bacteria were cultured at $37^{\circ} \mathrm{C}$ for $24 \mathrm{~h}$ and the dish inoculated fungi and yeast was cultured at $28^{\circ} \mathrm{C}$ for $48 \mathrm{~h}$, and then diameter of inhibition zone was measured.

\section{Agar Diffusion Plate Method}

The different kinds of microbe containing medium were prepared by blending $10 \mathrm{~mL}$ different microbe suspensions with $150 \mathrm{~mL}$ corresponding media after being sterilized and cooled down to $45^{\circ} \mathrm{C}$. $12 \mathrm{~mL}$ sterile medium was added into a $120 \mathrm{~mm}$ sterile culture dish to form the bottom medium when it was solidified; then,
$6 \mathrm{~mL}$ microbe containing medium was poured upon the surface of the bottom medium and shaken until dispersing uniformly to form the top medium. Leathers were cut into circular samples with a diameter of $18 \mathrm{~mm}$ and the samples were placed on center of the dish. The dish inoculated bacteria were cultured at $37^{\circ} \mathrm{C}$ for $24 \mathrm{~h}$ and the dish inoculated fungi and yeast was cultured at $28^{\circ} \mathrm{C}$ for $48 \mathrm{~h}$, and then diameter of inhibition zone was measured.

\section{Improved Halo Method}

The different kinds of microbe containing medium were prepared by blending $10 \mathrm{~mL}$ different microbe suspensions with $150 \mathrm{~mL}$ corresponding media after being sterilized and cooled down to $45^{\circ} \mathrm{C}$. $12 \mathrm{~mL}$ sterile medium was added into a $120 \mathrm{~mm}$ sterile culture dish to form the bottom medium when it was solidified; then, $6 \mathrm{~mL}$ microbe containing medium was poured upon the surface of the bottom medium and shaken until dispersing uniformly to form the top medium. Some marks were signed on the back of the plate; the spacing between each mark was larger than $25 \mathrm{~mm}$ and the distance from every mark to edge of the plate was greater than 15 $\mathrm{mm}$. Leather were cut into circular samples with a diameter of $5 \mathrm{~mm}$ and the samples were placed on surface of the top medium, in addition, the center of each sample should coincide with the mark. The dish inoculated bacteria were cultured at $37^{\circ} \mathrm{C}$ for $24 \mathrm{~h}$ and the dish inoculated fungi and yeast was cultured at $28^{\circ} \mathrm{C}$ for $48 \mathrm{~h}$, and then diameter of inhibition zone was measured.

\section{Repeatability Analysis}

Every experiment was repeated 6 times, and the data was analyzed by the statistical software of SPSS 17.0. The repeatability and the reliability were analyzed by the consistency and the intraclass correlation coefficient (ICC) value. 


\section{RESULTS AND DISCUSSION}

\section{Evaluation of Antibacterial Activity by Different Methods}

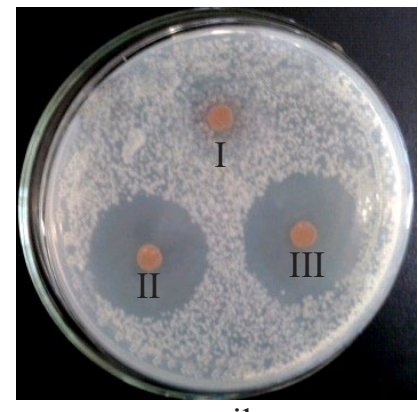

nano-silver

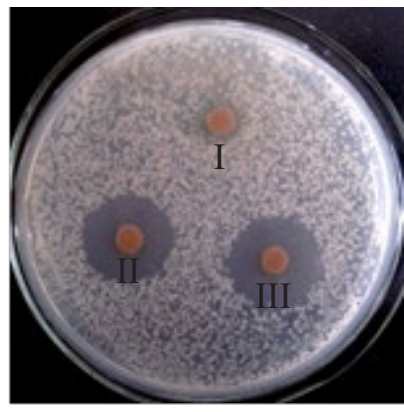

butyl paraben

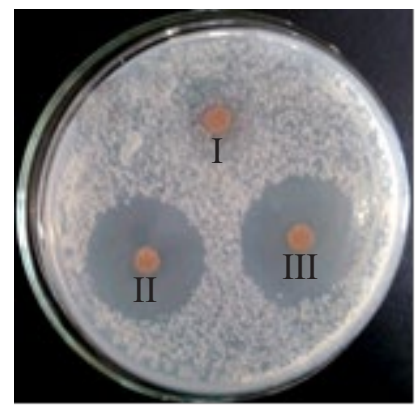

nano-ZnO

Figure 1. Antibacterial activity against Escherichia coli evaluated by improved halo method (I: blank sample, II and III: antibacterial samples)

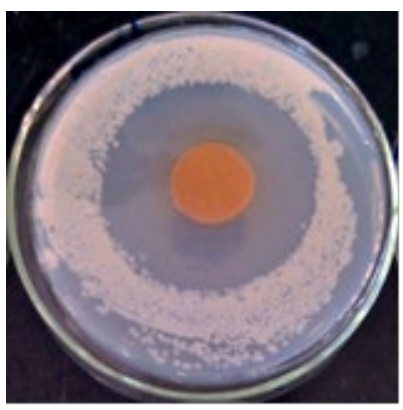

nano-

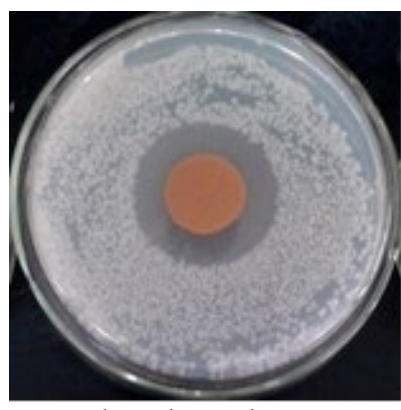

butyl paraben

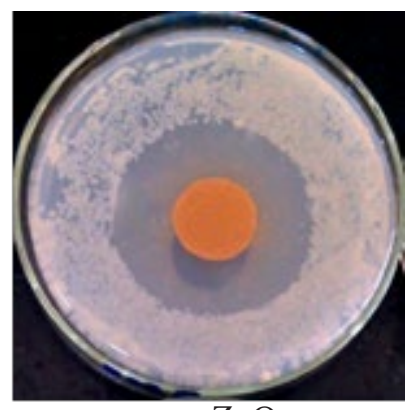

nano- $\mathrm{ZnO}$

Figure 2. Antibacterial activity against Escherichia coli evaluated by halo method

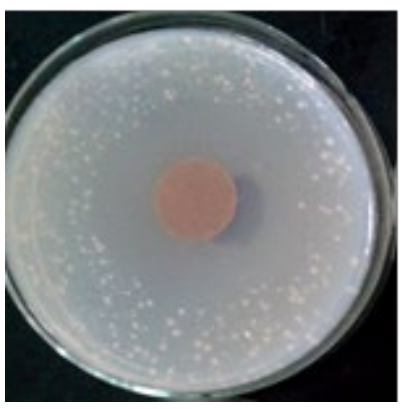

nano-silver

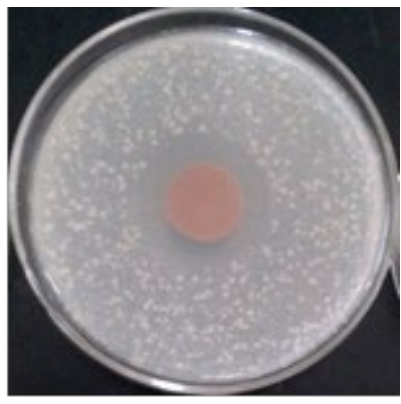

butyl paraben

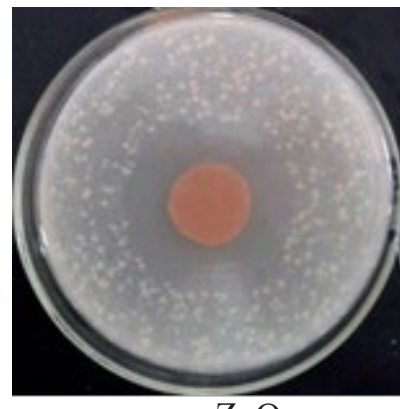

nano- $\mathrm{ZnO}$

Figure 3. Antibacterial activity against Escherichia coli evaluated by agar diffusion plate method

The antibacterial activity of different leathers treated by three kinds of antibacterial agent was evaluated by improved halo method, halo method and agar diffusion plate method, and the results are shown from Figure 1 to Figure 3. It is clear that there are obvious inhibition zones around leather samples treated by antibacterial agents with improved halo method but no inhibition zone around blank sample; therefore, the new method is valid. The improved halo method is upgraded based on halo method and agar diffusion plate method. In traditional halo method, bacteria or fungi are coated onto the surface of medium by hand; consequently, the distribution of microbes is not uniform during reproduction (Figure 2). In traditional agar diffusion plate method, microbes are mixed with media under shaking, but only one sample could be tested in one culture dish (Figure 3 ). It is not suitable for plenty of experiments. In improved 
halo method, microbes are distributed evenly onto medium and more than one leather sample could be evaluated in one dish simultaneously, both efficiency and accuracy would be improved.

\section{Repeatability and the Reliability of Different Methods}

Table 1: Repeatability and reliability analysis of improved halo method

\begin{tabular}{cccccc}
\hline Microbe & Antibacterial agent & Average $(\mathrm{mm})$ & RSD $(\mathrm{mm})$ & ICC & $\mathrm{P}$ \\
\hline \multirow{3}{*}{ Escherichia coli } & nano-Ag & 32.55 & 0.98 & 0.884 & 0.001 \\
& butyl paraben & 19.62 & 0.71 & 0.733 & 0.019 \\
& nano-ZnO & 25.38 & 0.92 & 0.883 & 0.001 \\
Staphylococcus aureus & nano-Ag & 37.65 & 0.96 & 0.995 & 0.000 \\
& butyl paraben & 31.59 & 0.92 & 0.825 & 0.004 \\
& nano-ZnO & 42.79 & 0.90 & 0.723 & 0.022 \\
Aspergillus niger & nano-Ag & 35.52 & 0.84 & 0.976 & 0.000 \\
& butyl paraben & 10.66 & 0.79 & 0.927 & 0.000 \\
Rhodotorula & nano-ZnO & 31.23 & 0.96 & 0.873 & 0.001 \\
mucilaginosa & nano-Ag & 35.70 & 0.99 & 0.875 & 0.001 \\
& butyl paraben & 17.27 & 1.06 & 0.757 & 0.014 \\
& nano-ZnO & 39.24 & 0.87 & 0.988 & 0.000 \\
\hline
\end{tabular}

Table 2: Repeatability and reliability analysis of halo method

\begin{tabular}{|c|c|c|c|c|c|}
\hline Microbe & Antibacterial agent & average (mm) & $\mathrm{RSD}(\mathrm{mm})$ & ICC & $\mathrm{P}$ \\
\hline \multirow{4}{*}{ Escherichia coli } & nano-Ag & 48.44 & 0.71 & 0.875 & 0.020 \\
\hline & butyl paraben & 31.60 & 1.73 & 0.980 & 0.000 \\
\hline & nano-ZnO & 45.60 & 0.94 & 0.853 & 0.028 \\
\hline & nano-Ag & 56.63 & 1.09 & 0.901 & 0.012 \\
\hline \multirow[t]{3}{*}{ Staphylococcus aureus } & butyl paraben & 36.69 & 0.80 & 0.814 & 0.044 \\
\hline & nano-ZnO & 49.46 & 0.90 & 0.923 & 0.007 \\
\hline & nano-Ag & 60.80 & 1.20 & 0.931 & 0.005 \\
\hline \multirow[t]{3}{*}{ Aspergillus niger } & butyl paraben & 33.75 & 1.29 & 0.789 & 0.056 \\
\hline & nano-ZnO & 63.22 & 1.06 & 0.808 & 0.047 \\
\hline & nano-Ag & 52.74 & 0.50 & 0.555 & 0.198 \\
\hline \multirow[t]{2}{*}{ Rhodotorula mucilaginosa } & butyl paraben & 39.08 & 1.30 & 0.841 & 0.032 \\
\hline & nano-ZnO & 55.45 & 1.28 & 0.933 & 0.011 \\
\hline
\end{tabular}

Table 3: Repeatability and reliability analysis of agar diffusion plate method

\begin{tabular}{cccccc}
\hline Microbe & Antibacterial agent & mean $(\mathrm{mm})$ & $\mathrm{RSD}(\mathrm{mm})$ & ICC & $\mathrm{P}$ \\
& nano-Ag & 42.89 & 1.64 & 0.979 & 0.001 \\
Escherichia coli & butyl paraben & 31.01 & 1.45 & 0.927 & 0.013 \\
& nano-ZnO & 41.08 & 1.57 & 0.977 & 0.002 \\
\multirow{3}{*}{ Staphylococcus aureus } & nano-Ag & 46.09 & 1.31 & 0.888 & 0.028 \\
& butyl paraben & 34.27 & 1.84 & 0.988 & 0.000 \\
& nano-ZnO & 46.49 & 0.59 & 0.848 & 0.048 \\
Aspergillus niger & nano-Ag & 49.27 & 1.07 & 0.756 & 0.100 \\
& butyl paraben & 29.05 & 1.18 & 0.860 & 0.042 \\
& nano-ZnO & 54.16 & 1.63 & 0.971 & 0.002 \\
Rhodotorula mucilaginosa & nano-Ag & 52.09 & 1.93 & 0.951 & 0.006 \\
& butyl paraben & 35.93 & 1.64 & 0.847 & 0.048 \\
& nano-ZnO & 52.25 & 1.92 & 0.977 & 0.002 \\
\hline
\end{tabular}


Antibacterial activities of leathers treated with three kinds of antibacterial agents were evaluated by improved halo method, halo method and agar diffusion plate method, and the results are listed from Table 1 to Table 3 , in which average is inhibition zone diameter in different tests; RSD is relative standard deviation of test results; ICC is intraclass correlation coefficient; $P$ smaller than 0.05 means results are statistically significant. The range of ICC is from 0 to 1 , and higher value means better reliability. ICC lower than 0.25 means poor consistency; ICC from 0.25 to 0.49 means low consistency; ICC from 0.50 to 0.69 means poor medium consistency; ICC from 0.70 to 0.89 means good consistency; ICC from 0.90 to 1.00 means excellent consistency.

As is shown in Table 1, all ICC values are greater than 0.70 but all $P$ values are less than 0.05 , indicating the antibacterial activities results from improved halo method are reliable and repeatable. Compared with halo method (Table 2), the new method brings about higher ICC value but lower $\mathrm{P}$ value as the microbes are distributed evenly onto medium surface. The ICC value and $P$ value in the new method is comparable with agar diffusion plate method (Table 3 ), so it could conclude that more than one samples tested in one culture dish would not impair evaluation accuracy.

The results in Table 1 to Table 3 also suggest that nano-silver brings about better antibacterial activities against Escherichia coli and Staphylococcus aureus and nano-ZnO results in better antibacterial activities against Aspergillus niger and Rhodotorula mucilaginosa. Since butyl paraben is poorly soluble in water, the antibacterial activity is the poorest.

\section{Application of the Improved Halo Method}

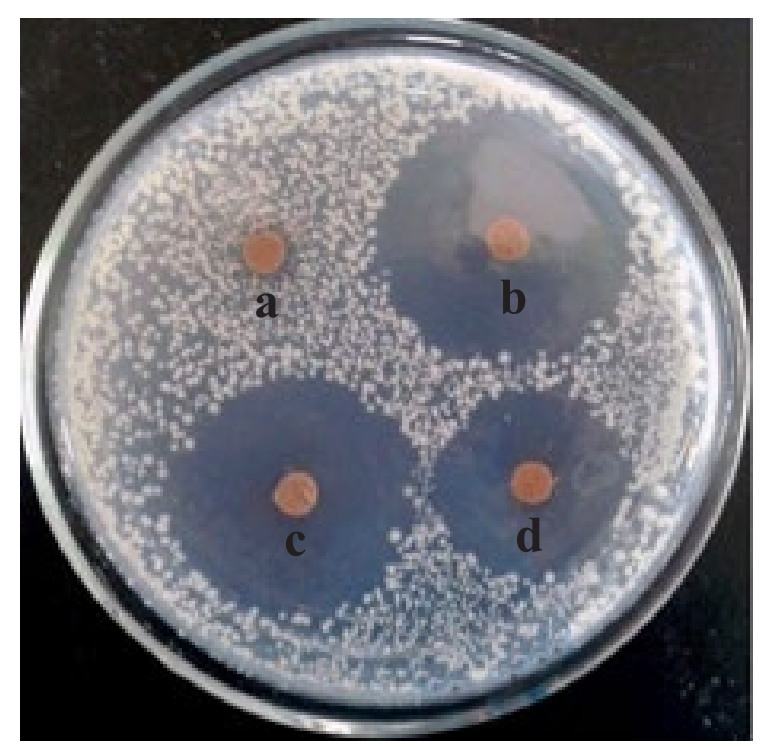

Figure 4. The antibacterial activity of different samples against Escherichia coli tested by improved halo method (a - blank; b - nano-silver; c - nano-Zno; $d$ - butyl paraben)

Figure 4 illustrates that four samples could be tested in one culture dish for evaluating antibacterial activities against Escherichia coli. The diameter of inhibition zone from big to small is nano-silver, nano-ZnO, butyl paraben and blank, and the difference between each sample is very clear and intuitive. Therefore, improved halo method could not only be used for evaluating leather antibacterial activity quantitatively but it is also a fast and qualitative analysis method.

\section{CONCLUSIONS}

An improved halo method was developed based on traditional halo method and agar diffusion plate method for evaluating leather antibacterial activity quickly, intuitively and 
precisely. In the method, microbes were blended with sterile medium directly and double layer medium was used to avoid error from uneven distribution of microbes, and more than one sample could be tested in one culture dish for evaluating antibacterial activity. Antibacterial activity against various bacteria, fungi and yeast could be evaluated by improved halo method, and antibacterial activity of leather treated by different antibacterial agents could be tested by the method too. Moreover, the repeatability and reliability of new method was excellent, and the results were not only quantitative but also intuitive. In sum, improved halo method would be a new choice for leather evaluating antibacterial activity rapidly and precisely.

\section{Acknowledgements}

The authors wish to thank the financial support of Scientific Research Project of Guangdong Administration for Market Regulation (2020ZZ15).

\section{REFERENCES}

1. Velmurugan, P., Park, J.H., Lee, S.M., Jang, J.S., Lee, K.J., Han, S.S., Lee, S.H., Cho, M., Oh, B.T., Synthesis and characterization of nano silver with antibacterial properties using Pinus densiflora young cone extract, J Photochem Photobiol, 2015, 147, 63-68, https://doi. org/10.1016/j.jphotobiol.2015.03.008.

2. Velmurugan, P., Vedhanayakisri, K.A., Park, Y.J., Jin, J.S., Oh, B.T., Use of Aronia melanocarpa fruit dye combined with silver nanoparticles to dye fabrics and leather and assessment of its antibacterial potential against skin bacteria, Fibers Polym, 2020, 20, 302-311, https://doi.org/10.1007/s12221-019-8875-2.

3. Kaygusuz, M., Application of antimicrobial nano-materials on leather: a review, J Soc Leath Tech Ch, 2017, 101, 173-178.

4. Yang, W.T., Li, H., Gong, Y., Chen, W., Gaidau, C., Preparation of silver nanoparticles of enhanced antibacterial effect with benzalkonium bromide, $J$ Optoelectron Adv
Mater, 2011, 13, 661-665.

5. Xia, Y., Chen, W.Y., Zou, Y.K., The anti-microbial property of bovine hide sleeping mat leather, Leather Science and Engineering, 2012, 22, 2, 55-58.

6. Tang, Q.Y., Yang, Y., Zhang, J.W., et al., Application of nano silver composite antibacterial agent in shoe lining leather, China Leather, 2014, 43, 11, 11-13, 18.

7. Yang, W.T., Wang, X., Gong, Y., Li, H., Chen, W., Gaidau, C., Preparation of antibacterial sheepskin with silver nanoparticles, potential use as a mattress for pressure ulcer prevention, J Am Leather Chem Assoc, 2012, 107, 85-92.

8. Zhang, J.W., Wu, J.C., Wang, Y., et al., Technology of the antibacterial sheep fur, Leather Science and Engineering, 2013, 23, 5, 24-29.

9. ISO 16187 - "Footwear-Test methods for uppers, lining and insocks-Antibacterial activity".

10. Falkiewicz-Dulik, M., Biocidal activity of selected preparations for leather protection, Fibres Text East Eur, 2020, 28, 115-122, https://doi.org/10.5604/01.3001.0013.5866.

11. Koizhaiganova, M., Yasa, I., Gulumser, G., Assessment of antibacterial activity of lining leather treated with silver doped hydroxyapatite, Int Biodeterior Biodegrad, 2015, 105, 262-267, https://doi. org/10.1016/j.ibiod.2015.09.017.

12. Li, H., Zhao, C.Q., Zhou, J., Shao, H., Chen, W., Isolation, purification and identification of bacteria from the shoes worn by children, Afr J Biotechnol, 2012, 10, 4133-4137.

13. Li, H., Zhou, J., Shi, R., Chen, W., Identification of fungi from children's shoes and application of a novel antimicrobial agent on shoe insole, Afr J Biotechnol, 2012, 10, 14348-14354. 
14. Li, H., Zhou, J., Yang, W.T., et al., Research on the preparation and properties of children shoes insole with microbial resistance function, China Leather, 2010, 41, 4, 102105.

15. Li, H., Yang, W.T., Zhou, J., et al., Disposition of Antimicrobial agents and effect evaluation on children's insole, Leather Science and Engineering, 2010, 20, 6, 20-23.
(C) 2020 by the author(s). Published by INCDTPICPI, Bucharest, RO. This is an open access article distributed under the terms and conditions of the Creative Commons Attribution license (http:// creativecommons.org/licenses/by/4.0/). 